\author{
クレシュ，ダイアン $\mathrm{N} .{ }^{1}$ : 著
}

高木和子 ${ }^{2}:$ 訳

\begin{abstract}
著者抄録 : 米国議会図書館とその協力図書館（現在, 米国内および国外の16の図書館が参加）がパイ ロットテストを経て2002年6月に開始したデジタルレファレンスサービスであるQuestionPointについ て述べる。これはどのようにして図書館のレファレンスサービスをサイバースペースに移行できる かの問いに対するひとつの回答であり, また, 新テクノロジー時代にあって, ライブラリアンが直 面するチャレンジでもある。近年, WWWの成長がめまぐるしい。Webコンテンツの数は途方もなく 増加を続ける。しかし, 実際にはWebは複雑で利用しにくい。信頼性が高く, 有用なコンテンツを 見つけ出したいというユーザニーズを満たすには, 従来のレファレンスサービスの手法は依然とし て重要である。すなわち, それはライブラリアンが情報ニーズをしっかり把握し, 図書館の組織化 された情報資源を駆使し, かつピアレビュー済みとも言えるレファレンス回答を提供できるからで ある。これら手法も意識したデジタルレファレンスの組織, 管理および協力図書館のネットワーク の構築, 機能に関与する3つの構成要素；1) 協力図書館で構成されるコンソーシアム内で, 該当図書 館にレファレンス質問を割り振るローカルなネットワーク 2) さらにローカルなレベルを超えてレ ファレンス質問をグローバルなレベルで図書館に割り振るネットワーク 3 ) 過去のレファレンス質 問の回答を保存し，それを現実のレファレンス質問に活用するアーカイブであるナレッジデータ ベース，について述べる。今後の方向とこれまでに得られた教訓にも触れる。

キーワード : 米国議会図書館, QuestionPoint, デジタルレファレンスサービス, WWW, 図書館ネッ トワーク, レファレンス回答データベース
\end{abstract}

\title{
High touch and high tech
}

\section{-QuestionPoint as a model for the future of reference-}

\section{written by KRESH, Diane N. ${ }^{1}$ translated by TAKAGI Kazuko²}

\begin{abstract}
Author Abstract: The author describes QuestionPoint started in June 2002 after the pilot test over certain period. QuestionPoint is a digital reference service which is the joint service among the Library of Congress and currently 16 cooperative libraries not only inside the U.S. but also in other countries. QuestionPoint is one response to how traditional reference services of libraries can handled on the cyberspace. It is also a challenge librarians are facing under the circumstance of IT technology. We have seen fast-moving growth of WWW. Web contents are increasing at the tremendous speed on the Internet. We, however, find those Web contents not easy to find or locate information we exactly need. In order to meet users' needs, libraries still play an important role backed up with the proficiency in grasping those users' information needs, with well-organized and subject-oriented information resources inside and with peer-reviewed reference results. The author explains organization, management and cooperative libraries networking of QuestionPoint. Then she explains three components in the function; 1) within the consortium consisting of the cooperative libraries reference questions are assigned to the appropriate library which is supposed to answer (local libraries network), 2) beyond the local network reference questions are assigned to the appropriate library (global network), and 3) archiving the reference questions/answers (so-called knowledge database) and getting the database available for incoming reference questions. She mentions the future direction and lessens being learned.
\end{abstract}

Key words: Library of Congress, QuestionPoint, digital reference service, WWW, library network, reference answer database 


\section{1.はじめに}

オンライン情報の急増と, インターネットや商 業サーチエンジンの流行により, ライブラリアン には自己の職業を見直すことが求められている。 新しい要求と期待は, 圧倒的な量の情報が現在流 通していることから生じている。情報を遠隔地の 利用者向けに伝達する必要性が, 伝統的な図書館 サービスと新テクノロジーを連結する革新的な種々 のプログラムの創出に拍車をかけている。ライブ ラリアンは新しいサービスパラダイムに適応する というこれまでにない機会を持つに至り，そうす ることで現代社会に自らが関与していることを実 証するのである。ライブラリアンはほんの 10 年前, World Wide Webの出現以前は夢にすぎなかった事 柄をも上回る, 基本的かつ職務に根ざしたサービ スを提供するためにテクノロジーを利用できる。 どうしたらライブラリアンは信頼に足るアドバイ ザーとして, さらに確たるライブラリアンの立場 を築けるのだろうか。そしてどうしたら新しいニー ズを満たし, ライブラリアン職を再び活性化させ られるサービスをつくり出せるのだろうか。米国 議会図書館（Library of Congress）とその協力図書館 によって始めた, 現在QuestionPoint と呼ばれる Collaborative Digital Reference Service (CDRS) がそう いった問いに対するひとつの回答である。

\section{2. なぜデジタル化するのか?}

今日の図書館では人が介在するレファレンスを， インターネットを介して提供する方法が増加して いる。南カリフォルニアの13の公共図書館の共同 であるA24／7 Reference, オハイオ州クリーブラン ド公共図書館のインターネットサービスである Knowit Now 24／7,そしてニューヨーク州サフォー ク郡の「ライブ・ライブラリアン」は, このよう なインターネット上のレファレンスサービスを継 続するためにライブラリアンが変革を重ねるけん 引役となりつつあることを示している証拠である。

レファレンスライブラリアンのイメージもまた 変化しつつある。求人広告では, 革新的なツール とサービスを実施する際のチームを率いる, 精力 的で, ダイナミックかつ意欲にあふれた人間を求
める。1999年の初頭, Ann Lipowは, ライブラリア ンは図書館利用者の減少に留意し, よって図書館 利用者が情報を求めるそのとき, どこからでもレ ファレンスサービスを利用者の要求にこたえて提 供できる場を設定するよう警告した(Lipow著,1999 年)。Lipowはさらに, ライブラリアンは図書館か ら遠く離れた場所にいる利用者に対しても, 来館 者である利用者に対するのと同じように, わかり やすい, かつ便利な情報アクセスを提供できるよ うでなければならないと示唆した。

今や図書館にとって重大な時期である。つまり, 図書館の職務の方向を鼓舞して, 公共サービスを 描く機会が今であり, その場合, 情報へのオープ ンなアクセスを人々が確実に享受できるサービス でなければならないのである。この情報アクセス の自由とは, 市民が民主的プロセスに十分に参加 するうえで中核をなす。学校, 教会, 市民団体, ボ ランティア団体, 読書グループと共同する図書館, そして地域社会, これら両者ともに同時的にオン ラインで結ばれるのだが, それらは社会組織を形 づくり維持する中で重要な役割を果たす (Preer著, 2000年)。リーダーシップを発揮しつつレファレン スライブラリアンが担う努力は体系的にプールさ れ, 図書館の重要な使命, すなわちコミュニティ のニーズにこたえる使命を実施することになる。

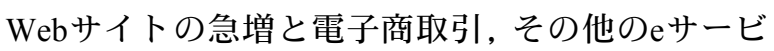
スの爆発は, 次のような機能を持つダイナミック な図書館プログラムにうまくはまるのである。

(1) 図書館の所蔵資料や資源をより広く世界中の利 用者にアクセスさせる技術を採用し，それに よってデジタルデバイドを縮小させる

(2) 図書館や研究用所蔵資料が普遍的で包括的であ り続けるように, 重要な出版物を電子形態で収 集・創造する

(3) 共同資産を生み出すために国内機関と国際機関 双方との協力体制を確立し, 図書館がその資源 を蓄積し, 保存し, アクセスを提供し, かつ拡 大できるようにする

(4) 図書館が伝統的イニシアチブと新しいイニシア チブの双方を充足できるように，技術的・戦術 的な革新の土㙵をつくる。というのも, デジタ ルライブラリーの可能性はそれをつくる人の想 像力だけで限定されてしまうからである 
ますます多くの利用者がオンラインに向かうに つれ，情報ニーズをどうしたら満足できるかにつ いての期待が高まる。人々はさまざまな情報ニー ズ, 例えばレクリエーション, 買い物, 健康や仕 事に関連する調べごと, オンラインニュースや金 融情報を求めてインターネットを今後も利用し続 けよう。そしてインターネットは多くの10代の才 ンライン利用者の情報ツールとして図書館に取っ て代わった(The Pew Internet \& American Life Project, 2001年)。この観察結果はワシントンポスト紙に掲 載された記事で裏付けられている。大学の教授は 学生たちがインターネットで必要なリサーチをす べてこなして, 図書館で提供される印刷体, 非印 刷体の情報資源の宝庫を無視していることにいら だっているとの内容の記事であった（Washington Post, 2002年7月16日 “Point. Click. Think?”)。

Markle Foundationは全アメリカ人の $63 \%$ ，オンラ イン利用者の $83 \%$ がインターネットに肯定的な見 方をしていることを見いだした (Markle Foundation， 2001年）。そのリサーチではさらに，人々がイン ターネットを主に情報源として認定していること を確認した。17\%の人々がインターネットを「ショッ ピングモール」，あるいは「銀行や投資オフィス」 になぞらえたのに対し $45 \%$ の々がインターネッ 卜に対する支配的イメージは「図書館」のイメー ジであると述べた。しかし，インターネットの人 気にもかかわらず, 調査対象の人たちのかなりの 部分がインターネット上のサイトの信ぴょう性を 危惧しており，インターネット上で知りえた内容 の大半が疑わしいと感じていた。

インターネット上に現れる書式に必要事項を記 入するだけでAskMe.comの正規の法律専門家になっ た15才のティーンエイジャーの話は, Web上の即 席専門家現象に伴う, 企業家精神の背筋が寒くな るような否定的な面を象徵している。Court T.V. (訳 者注：裁判情報を提供するテレビ局）を何年間も 見て学んだ「経験」から,この若者は自分が AskMe.comの刑法部門の約 150 人の専門家の中で 10 位にランクされたことを知ったが，これらの専門 家の大部分は本当の弁護士であった（New York Times Magazine，2001年)。

もし専門家になるのがかくも簡単であるなら， インターネット時代にあってライブラリアンの役 割は果たしてあるのか? 米国議会図書館の Collaborative Digital Reference Serviceに関する Associated Press（AP）の記事が出た後で実施された CNN利用者世論調査によれば，答えはイエスであ
る（Associated Press，2000年）。その世論調査は圧 倒的にこれを肯定した。すなわち，回答した利用 者の $90 \%$ は, 自分たちがすでに利用している商業 サービスよりも, 図書館をべースとしたWebサー チを好んでいると出たのであった。

\section{World Wide Webと図書館の相違点}

World Wide Webは成長を続けており（現在 800 万 サイトを擁する)，仲介も制限もないという環境の 中で情報を生成し配布する, 先例のない機会を提 供する。Web上で自由に入手することのできる情 報の広さは, そのWeb資源にさも容易にアクセス できるかのような誤った印象を与えるが，実際に はWebは複雑で利用しづらいものである。そのう えデジタル領域は, 印刷物環境を規制するライブ ラリアン, 出版社, ピアレビューの伝統を欠く。こ ういった 3 者による規制がないと，情報を探す人 は, 信頼性が高く権威もある, しかも歴史的に重 要で有用なコンテンツを見つけ出したいという希 望を持っていても, 秩序のないデータの山をくぐ り抜けざるをえない。Yahoo!は図書館利用者に人 気があるが,レファレンスッールとしては深刻な 欠陥を持つ（Cohen著, 2001年）。その記載情報の 大部分は商業Webサイトであり, リサーチ価值は 低い。最近開始されたGoogle Answersは料金を取っ て回答を提供するが，その情報源はWeb上で公に 入手できるものである。Google Answersのリサー チャーは主題専門家ではないので, Web利用者が その回答に満足できなかった場合はGoogleは料金 を返金する（Christian Science Monitor，2002年7月22 日, “Paying for answers online”)。便利さが商用AskAサービスの領域を支配している (Parsons著, 2001 年)。これらの利用者の質問への回答が, 図書館に ある膨大な所蔵資料からでも数千もの図書館オン ライン目録をサーチした結果でもなく，単にWeb 上で見られる情報だけを頼りにサーチした結果で あるとの錯覚を定着させてしまう。

一般的にWebの生産的な利用は次に挙げるいく つかの要素によって妨げられる。

・情報を目録する（または組織化）という伝統的 手法の不在

・信用できる（またはプロフェッショナルな）ナ レッジ生産者と, 信用できない（または非公式 な）ナレッジ生産者との区別の消失

·質が高く教育的で多様な, そして社会的に重要 なオンラインコンテンツの欠如 
- Web の短命な本質一Web をブラウズしていると, 1日に何度 “エラー404”，すなわち「ファイル見 つからず」に出くわすことか一インターネット 情報は, 今日はあっても明日はなくなるという 現象がしばしば起きる

人のつくり出した知識の膨大な資料を持つ図書 館は, 情報を掘り起こす計り知れないほど大きな 機会を提供する。それゆえ図書館はボランティア の労働に頼るよりも, 何年にもわたる経験に基づ く知識を持ったレファレンスや主題の専門家を配 置する。図書館は多くの点でWebとは異なる。例 えば困書館は,

・資料にアクセスできるようにするため, 統制語 やその他の標準ツールを使って情報を組織化する

・資料を選書する前に, それらを図書館で設定し ている選書方針やガイドラインに従って細心に 評価する

・印刷物, 非印刷物, デジタル形態を収納する

・利用者が来館して, 手紙で, 電話で, ファック スで,Eメールによるオンラインでアクセスでき るようにする

・対面レファレンス面接を通して利用者のニーズ を評価する

図書館の特質つまり体系と組織化, 深い主題知 識, 困書館利用者のニーズへの感度, コミュニティ が確認した基準と最良の業務, そしてアナログの 所蔵資料などは，インターネット上で提供される 情報, つまり, 体系化も立証もされていないそれ らとは対極的である。

\section{4. 利用者のいるところに出向く}

それでは, 我々はどのようにしてレファレンス デスクをサイバースペースに移行するのか。現在, QuestionPoint と呼ばれるCollaborative Digital Reference Service（CDRS）は, 図書館利用者がどこ にいようと, 図書館が相互に助け合って利用者に サービスできるようにするものである。情報の探 索, 体系化, および確証の専門家であるライブラ リアンで構成されるWebべースのネットワークを 通して, QuestionPointは1日24時間, 週に7日間休ま ず,それぞれの図書館の所蔵資料のパワーとユニー クさと, それら図書館およびライブラリアンの多 様性と起動性を結び付ける。

議会図書館は1998年に,「デジタル時代のレファ レンスサービス」と呼ばれる会議を召集した際に, 図書館利用者のための共同ネットワークづくりへ
の道を導き始めた。我々のゴールはレファレンス ライブラリアンを集めて, 本や印刷体レファレン ス資料（そして推測するに図書館とライブラリア ン）の消滅が差し迫っているとの予言が広まって いる時代に,レファレンスサービスやニーズにつ いて討論することであった。学術界の多くの人々 が当時 (そして今でも), 学生たちがリサーチを行 う際, Webにしかアクセスしないと懸念し, そし て, 学術界もオンラインに入り込むか, もしくは 情報利用者を急成長しているドットコムに委譲す る必要があると感じていた。

1998年の会議で出た結論は, 図書館間の協力拡 大こそ図書館の電子資源と印刷体資源双方を統合 したレファレンスサービスの将来にとって必要不 可欠であるとライブラリアンたちが認識したこと だった。職業上の協力は常に強力である。困書館 はこれまでも所蔵資料を保存し, 資料の目録を作 成し, 資料へのアクセスを可能にし, 所蔵資料を 相互に貸し出し, 最近ではバーチャルな図書館を つくり出すために協力してきた。ここに，レファ レンスの専門技術をオンラインで共有することに 何ら異存はないゆえんである。

2000年春に米国議会図書館はCDRSの構築を開始 し, あらゆる種類の図書館 (国立, 学術, 専門, 公 共図書館）がこのプロジェクトに参加することを 求めた。それぞれの図書館は, 自館のこれまでの 経験やそこでの利用者の行動とニーズの知識, そ して専門とする主題知識を持ち寄った。事実, CDRS が急速に発展したのはプロジェクト初期に参加し たメンバー図書館の所蔵資源の豊富さと洞察の必 然的結果であった。

\section{CDRS：組織および運営前提}

米国議会図書館とともにCDRSをつくり, 共同レ ファレンスサービスのビジョンを共有する16の四 書館とは, 次のとおりである:国立農学図書館 (U.S. National Agricultural Library), オーストラリア国立図 書館, カナダ国立図書館, スミソニアンアメリカ ンアートミュージアム (米国), テキサス大学オー スティン校, コーネル大学, サンタモニカ公共図 書館, モリス郡公共図書館 (米国), 北カリフォル ニア湾エリアのPeninsula Library System, ワシント ン大学, Vanderbilt University, アリゾナ州立大学, 南 カリフォルニア大学, Metropolitan Cooperative Library System（ロサンゼルス地域）, Ask ERIC, EARL Consortium（英国）。我々はCDRSを開発し実行する 
際のビジネスルールと運営のコンセプトをこれら パートナー図書館と共同で明確に定めていたため, 共同の本質は最初からはっきりしていた。コンセ プトを完全に立証するために一連のパイロットテ ストを設定した。最初の本番の質問を2000年6月 29 日に実行した。ビザンチン時代の料理に関する質 問で, 回答が英国の参加公共図書館コンソーシア ムであるEARL Ask-A-Librarianから送られてきた。ワ シントンにある米国議会図書館のCDRSサーバがこ の質問を受け取り，主題をべースに照合させ，そ の日のうちの午前 10 時 40 分にサンタモニカ公共図 書館に転送された。数時間後に該当する5冊の図書 のリストがロンドンに送られた。テストは成功し， ここにサービスが開始された。本番テストが行わ れた最初の月だけで, メンバー図書館・大学・コ ンソーシアムは, 3 大陸にわたり15時間帯をカバー するバーチャルレファレンスデスクを形成し, 300 以上の質問と回答を交換した。

最終的なパイロットテストは, 2000年の晚秋か ら2002年6月のQuestionPointの開始まで行われた。こ の最終的なパイロットテストの段階では, ワーク フローの拡大とオンラインプロファイリングのツー ル, 手作業によるバックアップシステム,「ライブ チャット」の構成要素である「オンコール（電話 呼び出し) ライブラリアン」, ナレッジベースのプ ロトタイプといったいくつかの機能の実施に重点 を当てた。ワークフローを設計して新規管理機能 を加えた。これによりレファレンス質問を割り振 られた図書館が, その割り当てが適切ではないと 判断した場合, その質問を断って別の図書館に振 り向けること, レファレンス質問の割り当て量が 満杯になってしまった図書館はこのレファレンス サービスから一時避難することができるようになっ た。2001年夏に「オンコールライブラリアン」が 実施されるようになったので, 以降どんな質問も システムの中で迷子にならなくなり, CDRSで処理 できないレファレンス質問でもテクニカルサポー 卜を受けられるようになつた。2001年に3つのマー ケットリサーチを行い, よって, CDRSの計画立案 者は次の事柄が行えるようになった。

・ 電子レファレンスの方向を決める産業動向, 課 題, ニーズ, および期待を理解する

・電子レファレンスサービスを図書館が適用する 場合, それを加速したり, 遅延させたりする要 因を確認する

・図書館にとって最も大きな重要性を持ち, CDRS に組み入れられるべき電子レファレンスの機能

\section{を決定する}

·電子レファレンスの機能の好ましいパッケージ とCDRSの価格サポートを確立する

合同のマーケットリサーチには世界中のあらゆ るタイプの (例えば公共, 大学, 国立, 専門) 図書 館を代表する計625名の参加者が加わった。一連の インタラクティブなセッション（参加者が電子投 票を行ったり, 基本的な問題を討論したワーク ショップ）およびインターネット調査から, 情報 や意見が得られた。このマーケットリサーチは大 変に生産的であり, いくつかの主だった結論が導 かれた。

・需要が増え, 利用者の期待が上がり続けるにつ れ，図書館の情報資源がさらに利用されていく ・レファレンスの質問が専門化し, 詳細化し, 複 雑になるに従い, 1図書館の壁を超えて図書館資 源を充実させ, アクセスするためのさらなる努 力が求められる

・情報資源を共有し, 利用者により良いサービス を広げるための協力を図書館相互で行うという 強い合意がある

・電子レファレンスサービスを発展させる関心は 非常に強く,この関心が基本的にレファレンス ライブラリアンの職業を変えていこう

・情報の質こそ, CDRS にとって唯一最も重要な性 能属性である

・図書館は CDRS にスタッフ資源を喜んで投入する 用意がある

QuestionPointをさらに開発するためにこれらの結 論が利用された。

\section{QuestionPointはどのように機能する のか?}

QuestionPointは次の3つの構成部分から成るモ ジュール式システムである。すなわち，地域の図 書館で形成するコンソーシアム内の図書館相互間 でレファレンス質問を割り振るというローカルな 構成要素, レファレンス質問の回答に最も適した 図書館を地域図書館のレベルを超えて探し出すた めのグローバルなネットワーク構成要素, そして レファレンス質問に即答できるように, 過去に処 理されたレファレンス質問の回答をアーカイブし てある構成要素である。

図書館利用者が最寄りのCDRS参加図書館に質問 を送ると, その参加図書館は自館で回答してもよ いし, もしくはグローバルネットワークに問い合 
わせる。レファレンス質問をグローバルレベルで 転送する場合, まず, 各参加図書館のプロファイ ルを蓄積しているプロファイルデータベースの フィールドデータとその質問内容が合致するかコ ンピュータで照合する。この図書館のプロファイ

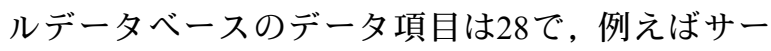
ビス時間, 特徵的な所蔵資料, スタッフ得意主題 分野と言語, 図書館利用者の教育レベル, 取り扱 う言語, 利用者の住居ないし職場地名, 図書館独 自のサービス, などである。この情報は表にして あり，よってレファレンス質問管理ソフトがこの 表を参照して, 質問をソートし, 付与し, 追跡し, 一方, エンドューザに回答を送ることができる。 参加図書館はこのプロファイルを完全にコントロー ルできるので, 自館のプロファイルを広くしたり， もしくは狭くしたり, 自由にコード化する。プロ ファイルッールはオンラインで設定されているの で, レファレンス質問の自動的割り振りに影響す るようなスタッフの人事異動であるとか, 特殊な 事情を反映する更新をフレキシブルに定期的に行 える。

例えば，もし図書館の文学スペシャリストが数 か月の有給休暇に入り, その欠員を補充できない のであれば，図書館はそのスタッフが戻ってくる までプロファイルからこの文学スペシャリストが 得意とする主題分野を除去してもよい。

\section{7. 情報のリサイクリング : QuestionPointナレッジベース}

なぜナレッジベースをつくるのか?ライブラリ アンはQuestionPointのナレッジベースを通せば, 権 威あるピアレビューされた情報資源へのアクセス ができる。ライブラリアンは, 無数に同じ回答を 作成しなくてもいいように一般的なレファレンス 質問を共有できるので, 重複の可能性を削減でき る。QuestionPointにかかわるライブラリアンの手で 八力される多様な, かつ信頼性の高い情報で構成 されるナレッジベースは,このデジタルレファレ ンスシステムのフロントエンド（最前線）として 機能するもので, レファレンス質問の回答群を蓄 積されたデータの中からしっかりととらえ, 提供 できるよう設計されている。ナレッジベースと合 致しない場合, そのレファレンス質問は再度シス テムに戻って割り当て先を探し, 該当図書館に割 り当てられる。

共同と合わせて, 編集上の援助も参加図書館か
ら要求されてきた。これは, 実際のレコードの編 集の助力というだけでなく, 臨時の編集会議の役 割も果たす。一般に, ナレッジベースの編集者は, レコードが偏見のないよう, そして客観性がある ようレビューする原稿編集者のようなもので, 品 質管理を確認し, 特定タイプのデータフォーマッ 卜（例えばURLや書誌事項）が基準に準拠してい るかを確実にする。編集プロセスの最終目標は, データベースのサーチの質を上げ, ブラウズし, 総体的にデータベースの使い勝手を良くすること である。加えて, QuestionPoint参加図書館がそれぞ れのレファレンス回答をナレッジベースに入力す る際, 事前にそれら回答に価值を付加するために, 共通のデータ入力操作を積極的に適用できるよう ガイドラインを現在作成中である。例えば，質問 や回答中に記載される個人情報（図書館利用者の 姓, 住所, 連絡方法, その他の利用者情報) やラ イセンス契約を結んだデータベースからの情報を 含むレコードの削除などである。後者のケースで は, もしそのようなデータベースの情報を直接引 用するとしても, 単に書誌事項やテキストであれ ば，それを言い換えるような回答を作成し直す。 いずれの情報もライセンス契約で利用しているデー タベースから直接とることもなければ, ましてや 回答の中にそのまま記載されることはない。編集 されたレコードはすべて次のような基本的情報を 含むことになるであろう。

(1) 関連主題領域へのつながりやリンクが確立でき るようにするために, レファレンス質問に関連 する管理データ

（2）キーワード, 件名標目, 分類情報

(3) レコードがシステムに入力された日付

(4) レコードが更新されるべきか否かとその頻度に 関する決定。例えば米国の第三代大統領名は, というレファレンス質問は時を経ても変わらな い。しかし, 米国の現大統領はだれかというレ ファレンス質問への回答は, その質問が出され た時点で変わってこよう。

(5) 情報源の書誌事項 : 著者, タイトル, 出版者, 出版地, 出版日, ID (例えばISBN, LCCN, カタ ログ番号, OCLC登録番号)

ナレッジベースをより確固な, すぐに使えるレ ファレンスッールにするには, 他の情報資源, 例 えば参加図書館の既製のレファレンスファイルや 電子レファレンス質問ですでに出された回答で構 成されるデータベースなどからのデータも入れ込 みたい希望はある。もしくは出版社との協定の下 
で提供されるコンテンツもナレッジベースでカバー することもできよう。QuestionPointのホームページ に免責条項が記載されている。それには，いずれ のレファレンス質問も, その回答も含めてナレッ ジベースのデータとしてカバーされる可能性があ り, ただし, 質問中の, そして回答中の個人情報 はナレッジベースに入力される場合除かれると記 載があり, また, プライバシーの保護も同様に記 載されている。

\section{8. システムに関する説明責任}

品質検閲の責任は, まず第一に参加図書館が負 うが, システム管理者（米国議会図書館側）と才 ンコールライブラリアンも定期的に検査をする。 現在検討されている品質管理課題に含まれる内容 は, レファレンス質問を参加図書館に割り当てる 前の同質問のパッケージ化(例えば,情報源のチェッ ク), 回答内容の要素, 費やされた時間, レファレ ンス質問者に渡される回答の適切性。説明責任は 重要な課題である。もし，ある図書館が自分の質 問を他の図書館に渡すならば，質問を再割り当て された図書館が質の高い回答を提供するためのあ らゆる努力を払うとの確信を, 質問を渡した図書 館は確信できるまでになっていなければならない。

レファレンス質問の回答と情報の品質管理にま ず取り組むために, QuestionPointのホームページは Virtual Reference Desk（VRD）Networkに参加するデ ジタルレファレンスサービスを創造し，維持する ための一連の基準であるFacets of Quality for Digital Reference Service（Virtual Reference Desk，2000年）に リンクする。レファレンス界は品質の評価をリサー チの最優先事項であると確認しており, 米国議会 図書館はCDRSに代わってデジタルレファレンス サービスの品質評価方法を開発するために実施さ れる研究への資金提供に参加した。2001年3月に始 まったこの研究は, Dr. Charles R. McClureの指導の 下に, Dr. R. David Lankesの助力を得てフロリダ州 立大学のInformation Use Management and Policy Instituteとシラキューズ大学のInformation Institute of Syracuseが行った。同研究からデジタルレファレン スのための多様な評価技術, サービスの尺度, 品 質基準が生まれた。この研究レポートはまもなく 公表される。

\section{QuestionPointの管理：諮問委員会}

QuestionPointの統括は, 参加図書館等機関の承認 を受けたそれら機関の代表で構成される諮問委員 会が行う。米国議会図書館とOCLC (オハイオ州ダ ブリン市にあるOnline Computer Library Center) はこ の委員会の常任委員であり, 諮問委員会の議長は 米国議会図書館が務める。諮問委員会は新規参加 機関の承認を含む機関参加方針を定め, 将来の方 向を描く。委員会の委員の構成はあらゆるタイプ の図書館をカバーするようになっており，そのう ち少なくとも2名の委員は海外の参加図書館の代表 である。

参加機関とのビジネス会議を定期的にもつので, フィードバックもでき, またワークフロー上の諸 問題を取り上げ, 解決を図ることもできる。

また, 研修であるとか達成度の測度を検討した りするので, 参加機関全体の団結心を育てられる。 参加図書館は常日頃, この共同こそ最も価值ある ものと見ている。共同が世界中の図書館利用者か ら寄せられるレファレンス質問に取り組むうえで の専門的な関係や洞察力の構築に役立つのである。 QuestionPointのホームページに一般的情報や新しい リンク, 参加図書館の情報, そしてプロジェクト のこれまでの画期的な出来事が掲載されている。

\section{0. ネットワークの構築}

QuestionPointの多数の構成要素をいかにフレキシ ブルに開発するかが, CDRSサービスの根本的な原 則のひとつとなっている。QuestionPointへの参加を 望む図書館にとってQuestionPointが価值あるもので なければならない。図書館は, それぞれが構造や 組織を異にしており, その利用者層も各館それぞ れで, 図書館の内容の質を保つ方針や処理手順も またそれぞれ異なる。図書館相互での仕事を進め るために, QuestionPointは参加図書館各館のサービ スの相互のギャップ,ニーズに見合った職員配置, 得意とする主題範囲を充実させる必要がある。さ らにそれぞれの図書館は, 通常その地域特有の所 蔵資料を持つ。こういった特殊資料は, 大規模研 究機関が満たせない䏚間 (ニッチ) を埋められる ので, QuestionPoint全体からして強力な武器となる。 参加図書館がQuestionPointとの関係はと尋ねられた ら,それはそういった参加図書館がCDRSの手はず を進んで行うと言えよう。米国議会図書館ではツー ルをつくり, 一方参加図書館はツールを最も効果 
的に利用するかを決定する。QuestionPointに参加す ると, 各参加図書館は以下を行えるようになる。

\section{・より良いサービスを提供する}

参加図書館はQuestionPointへの関与を次のような 機会であると見なすことが多い。各自の図書館の ビジョンを実行する機会, 職員増や労働時間増な しで図書館サービスを拡大できる機会, 四書館と その地域社会との間の連携を深める機会, 自館だ けでは回答できないようなレファレンス質問にも 回答を提供できる機会。

・新しく図書館利用者を開拓する

図書館は電子レファレンスを図書館利用者開拓 のツールとして利用している。ライブラリアンは テクノロジーを, 図書館を利用しない人々を新規 利用者として開拓する, Web上で若い世代との新 しい関係をつくり，彼らに知識資源をもたらすた めにWebを使用する遠隔教育をサポートする, な どを行う手段として見なす。

・価值のあるコレクションや資源にアクセスする

これはQuestionPointの最も刺激的な局面である と言われる。ライブラリアンは遠隔地の情報資源 や専門知識にアクセスできることを評価する。彼 らはまた, QuestionPointに参加すれば他の図書館 の情報資源をより費用効果的な方法で共有するこ とができ, たとえ自館の図書館予算が減少しても 知識へのアクセスを拡大する機会が与えられると 考える。彼らは世界中で同様の仕事をしているラ イブラリアン仲間とつながることに価值を見いだ す。つまり, 新しいツールや情報資源へのアクセ スを通して他の文化への見方や感受性を新鮮かつ 的を射たものとし, 他の文化への理解を育てるの である。

\section{1. 今後の方向}

2001 年1月にメンバー図書館を代表してOnline Computer Library Center（OCLC）と米国議会図書館 は, QuestionPointの次の開発に入るための共同協定 に署名した。この協定は2002年5月に更新された。 協定によれば, OCLCはQuestionPointに次の技術的 サポートと開発サポートを提供する。

• QuestionPoint を通してレファレンス質問の回答を 提供する参加図書館プロファイルデータベース の構築と維持

・ QuestionPoint 参加図書館がレファレンス質問の回 答を目録し, 検索やブラウズができるように蓄 積できる質問一回答データベースの構築と維持
・マーケティング

・ 新規参加図書館の登録

・研修と利用者支援を含むQuestionPointの管理サポ 一トの提供

米国議会図書館とOCLCは, 今後デジタルレファ レンスサービスが独立採算で実施できるための実 現可能なモデルを開発し, QuestionPointを図書館界 で振興させていく予定である。

現在QuestionPointの参加図書館は, 未端の図書館 利用者に代わって他の参加図書館と接続している ので, 図書館はパラメーターを定義し, 何ができ て何ができないかを判断し, 利用者のニーズを最 大限に満足させるサービスをつくり出すことがで きる。しかしながら, 我々は当初からQuestionPoint を末端利用者が直接利用できるサービスとして描 いてきた。人は往々にして, 図書館には出かけな くても情報は必要としているのだと我々は認識し ている。そして我々は, 人々が1日24時間, 毎日, どこからでもレファレンスサービスをライブラリ アンのネットワークから提供されるといった恩恵 に浴してほしいと考えている。今後数か月にわた り, QuestionPointはドキュメントデリバリープロ ジェクトを開発することにしている。これによっ て, 自動インターライブラリーローンを開始する ときに使用できるレファレンス質問・回答プロセ スの中から書誌情報を取れるようになる。これは レファレンス・情報サービスのワンストップショッ ピングを我々がつくろうとしているその第一歩で ある。

QuestionPointは, さまざまな利用者に質の高いレ ファレンスサービスの直裁的な利点をいくつか提 供する。例えば, ナレッジの専門的なナビゲーショ ン, 権威ある回答を検索できるような形態で保存 する, 図書館のどこからでもQuestionPointを人々に よりわかりやすいようにしたり, 図書館をサポー トするなどである。QuestionPointを通すなら, 図書 館は職員増や労働時間増を伴わずにサービスを拡 大させ, 地域社会と図書館とのかかわりを高める ことができるし,1館だけでは回答できなかったレ ファレンス質問に対しても回答を用意できること になる。QuestionPointは図書館に次のような機会を 与える。

・新しいダイナミックな方法で地域社会において そのサービスをさらに拡大する

・図書館に無縁な人々を図書館に引き付ける

・人々に知識資源をもたらすためにWebを利用した 遠隔教育を支援する 
・それぞれの図書館特有の所蔵資料へのアクセス を単にその地域社会のみでなく, グローバルに アクセスできるようにする。

それによって, たとえ図書館予算が減少し続け ても知識へのアクセスを拡大できる

我々は使命を満足させる権利を有し, 我々がつ くったシステムはライブラリアンが使いやすいも のであると確認するために技術的なソリューショ ンを絶えず調べ, かつ試験しているのである。我々 はまた, 1つのレファレンス質問の処理にかかる時 間に注目して,1つの参加図書館がいつQuestionPoint を利用し, いつの時点でその質問を自館の所蔵資 料だけで処理するかを判断する基準も開発中であ る。

\section{2. これまでの教訓}

QuestionPointは進化しつつあり, 進化に合わせて 継続的に参加図書館と連携して, 確実にそれら図 書館のニーズを満たせるサービスを展開している か否かチェックしている。参加図書館の多くは, いまだに取り組まなければならない多くの事柄が あることを気づかせるのに十分な案件を表明して くれている。例えば最も基本的なレべルでは, 図 書館でQuestionPointの実施が成功するには, それは スタッフのバイインと図書館の管理部門，すなわ ち学長, 副学長, 理事会のバイインに左右される。 どの四書館もそれぞれ事情が異なり, それぞれの やり方でバイインを得ようとする。我々がその利 用者にこのサービスを市場に出そうとしているよ うに, 眓書館もまた, そのスタッフにQuestionPoint のようなサービスを市場に出そうとするに違いな く, それは確かに利用者が必要としている, もし くは利用しようとする, そういったものでなけれ ばならない。

ライセンス契約の下で使用するデータベースを 適切に合法的に利用することを決定するのは, す べての図書館が直面する問題であろう。もしそれ が取り上げられていないならば, それは図書館が 効果的に共同するという能力をそいでしまう。困 書館は,技術的に見てサービス対象外の人々であっ てもかようなサービスを合理的に利用できるよう, 電子資源の出版社と創造的に, かつ勤勉に仕事を 進める必要があろう。

QuestionPointが世界的規模で拡大し, 真の意味で 1日24時間, 週7日のペースでサービスを行えるに つれ，検討しなければならない数多くの問題があ
る。言語とリテラシー, 自国語でその地域の利用 者にサービスを提供する, 文化的, 政治的に微妙 な問題のナビゲート, 価格設定に影響を及ぼすと される電子商取引と貿易協定である。2003年まで には非英語資料がインターネットのコンテンツの 半分以上を占めるとの認識は目の覚める思いであ る。こういった課題の解決がQuestionPointの長期的 な成功を決定づけよう。

互いのデータに互換性がなく, よってシステム 間でのデータ転送ができない, いわゆる孤立シス テムになる電子レファレンスサービスの開発を防 ぐために規格を設定することは重要である。その 目的のために米国議会図書館とOCLCは, ナレッジ ベースとプロファイリングツールの構築に使用さ れる相互操作性とメタデータの規格を確立するた め, National Institute of Standards Association（NISO） に参加している。これについての情報は<http:// www.niso.org>で見られる。

\section{3. 図書館は対面レファレンスで対応 しているか?}

今日の図書館は人々を必要なときに信頼できる 正確な資源にリンクさせるために, テクノロジー を利用する。QuestionPointは, より専門化した要求 を満たすため, 情報をより速くより効果的に利用 できるよう設計された専門的, 革新的で創造的な プロジェクトの中で実施されている多くの実験の ひとつである。

ライブラリアンにとって, 今はまぎれもなく自 分自身を再び創造し, 変ぼう自在な情報の世界の 要求に自分たちの技量を適応させるときである。 技術的進歩は図書館, 情報マネージャー, 研究者, そしてあらゆる種類の図書館利用者にとって新し い機会をつくり出している。事実, Webは情報を 収集し知識を獲得する方法を根本的に変化させた。 研究者は図書館に出かける代わりにまずWebに向 かう。しかしながらライブラリアンは信頼できる 助言者, 知識のナビゲータ, 管理者, 解説者, そ して情報と知識の仲介者と見なされている。我々 がこの役割を果たすのは, あらゆる人々が情報と 知識にアクセスする平等な権利を持つからである。 常に最新の情報と知識を提供できるようにするに は, 我々図書館人は変化のペースに順応しこそす れ, おびえを感じる必要は決してないが, 新規か つ,利用者に対してより応答的なプログラムやサー ビスを思い描くために変化のペースを取り込み, 
利用しなければならない。

レファレンスデスクからサイバースペースへの 変革はまだ初期段階にあり, 我々がいまだにその 全容をわかっていないので, 電子レファレンスサー ビスに関する懸念は根強く続いている。電子レファ レンスサービスはどのように機能するのか, 図書 館に適するかどうか, 公共のニーズを満たせるか といった懸念がしばしば聞かれる。そのような心 配はListservや専門職会議, トレーニングの場, ワー クショップで生じる「声に出して考える」プロセ ス, 我々が専門家として生き延びるのであれば持 ち続けなければならないプロセスの必要な部分で ある。図書館がますます多くの利用者サービスに かかわるにつれ, 多くの利用者は電子資源の利用 を期待し,さらに図書館資源が利用者のデスクトッ プに配布されることを期待するにつれ，図書館側 はこれまで親しんできた古いッールに頼らず, 新 規プログラムに着手するために必要とされる技量 を確認しなければならなくなる。すべての人が大 きなことを考えたいと思うわけでもなく，またそ れができるわけでもない。我々はどのようにして 創造的な思考や革新を教えるのか。図書館がまだ 設定していないならば，キャリア開発のプログラ ムを設けることが必要となろう。5年後に目録担当 者, レファレンスライブラリアン, あるいは他の スタッフが何をしているか, 我々はまったくわか らないが, デジタルイニシアチブの多くは, 我々 図書館職がどうなるか, そこに到達するために我々 図書館職に何が必要とされているかを模索するう えでのキーとなる。

QuestionPointはローカル図書館システムを強化す る。というのも, QuestionPointは初期の段階でかな りの時間を投入するので，単に資源を加えるだけ でなく, それぞれの図書館が従来的なサービス提 供方法を再考するチャンスを与えることにもなる からである。そのような再考があればこそ，今日 の図書館利用者がデジタルレファレンスサービス に何を望むかに配慮し，これまではなはだしく久 けていたある種のニーズ分析 (Assessing Quality in Digital Reference Service, Study Bulletin 090101 “What about the user?”）の開始を図書館側に行わせるので ある。こういった分析は, 図書館中心のシステム であるとかソリューションではなく，むしろ利用 者中心のそれらを結果としてもたらそう。そして， だれがデジタルレファレンスサービスを利用する かを定義するのに役立つだけでなく,利用者のニー ズをより効果的に満たせるサービスの定義にも役
立とう（Gray著，2000年）。

QuestionPointを通して,レファレンス処理をより 効率的でタイムリーにするために作業量, ソフト ウエアおよびデータベースを共有するパートナー が存在する。図書館の利用者は, QuestionPointがな ければ入手できないような専門情報を, 遠隔地の 機関に尋ねる機会も持てる。また, 利用者の最寄 りの図書館が閉まっているときでも質問への回答 を素早く得ることができよう。

QuestionPointは, 情報ニーズを求める利用者を図 書館に再度来館させる可能性ももたらす。それは コミュニケーションと資源共有のツールであり, 最寄りの眓書館がその地域社会にとって有意義な 情報源であることを気づかせるのに役立つ。参加 図書館はQuestion Point プロジェクトにさらにうま く取り組むためにも, このプロジェクトのニーズ とかかわりを明確にしていく必要がある。そして レファレンススタッフのバイインを得ることが必 須である。それは, 真に共同である必要があり, う まく進めるにはそれ以外の何者でもない。

\section{4. 結論：BothそしてAnd}

図書館人のほとんどが, 他人を助け, 公益に奉 仕し, 重要であろうとする考え方が好きで, ライ ブラリアンという職業に引き付けられてきた。し かし，そのライブラリアン職がもはや我々の認識 を超える何者かになりつつあるのではという不安 が増大しているのも事実である。テクノロジーの 利用の増加が, そもそも我々をライブラリアン職 に導いた原理を放棄するような機会になってはい けない。最も適切なレベルで利用者に奉仕するた めに細心に情報をパッケージすることは，いまだ に重要なゴールであるべきである。

我々が, 伝統的に利用者ニーズを知るための手 段としてきたレファレンスのための面接は, 今や 目には見えない場面で, 非常に頻繁に行われてい る。レファレンスのための面接は今もって図書館 サービスの本質的な部分ではあるものの, それを 目に見えない状況で行うのは，直接の面接に比べ て格段に複雑であるのだが。例えば，我々が利用 者との「生の会話」で利用者のニーズを引き出す となると, 時間もその分かかり, 我々が探してい る間, 利用者の興味をそのままの状態で引き伸ば すこと, これはぜひとも我々が行わなければなら ない試練である。我々はもつと頻繁に利用者に対 し, 例えば, 今探していますとか, この探索には 
数分かかりますとか知らせる必要があろう。処理 を終えるにはさらに数段階を経なければならない ことも覚えておく必要があろう。

我々は, テクノロジーのみが重要であるという 結論にとびつくべきでないし,「ツールをゴールと まちがえる」ようなことはすべきではない（Katz, 2001年)。我々は可能なときはいつでも書誌的指示 やレファレンス面接を通して, 利用者が学習のプ ロセスに参加し, サーチにもっと熟練できるよう に利用者教育を行わなければならない。テクノロ ジーを利用するか否かは適切さ, 必要性, そして ネットワーク能力に基づいて決めるのが望ましい。 まだ決めていないならば，まず異なるニーズを満 たせる数層的サービスの提供と, 図書館を利用者 にもたらす方法の開拓の両者について考えるべき である。

テクノロジーについて種々に我々が語るに合わ せて, 我々がこれまで行ってきた図書館サービス を放棄するときなどと考えることはない。そのと きではないことは，だれにとっても自明であるの だが (Bunge and Ferguson，1997年)。我々には依然 として, 図書館利用者全員のためにデジタル環境 の仕事を効果的に行う義務がある。その目的のた めに図書館は,テクノロジー統合, 全体的コンピュー 夕環境の維持, 機関内外での共同といった新しい サービス価值を探求する一方で, アクセスの公平 さを確保し，利用者のニーズを満たすサービスを カスタマイズし続けなければならない。これまで 専門職の議論は, 誤ったブーリアン演算子に焦点 を合わせてきたが, これは, 人間的触れ合いかハ イテクノロジーかの問題ではなく, 人間的触れ合 いANDハイテクノロジーであるべきである。

我々の境界·範囲を限定する地理的ふちどりが, 時間帯も無関係にするワイヤレスネットワークの 相互操作性の中に消えていくにつれ, 文化的な状 況や背景の中でこれまで見られた相違性も, ます
ます情報の発信や受信の中で姿があやふやになっ ていく。グローバルネットワークの技術的複雑さ は, 文化的・政治的な偏見や姿勢を防ぐよりもは るかに克服しやすいであろう。そして回答を作成 する際に設定する条件，それは例えば，質問を出 している利用者が地球の裏側にいる場合であれば, その回答の設定はまちがっているかもしれないし， もしくは地域的な背景を理解せずに出している回 答の条件のままであるかもしれない。つまり我々 は, 他の地域の人々が我々について知っているほ どには, 他の地域のことは知らない。我々西欧の 文化は非常に自己言及性が高く, 我々のメディア はどこにもあるのである。我々が自らの盲目性を 取り払い, 日々の我々の生活のあらゆる側面にま すますその影響を高める周りの世界と相互応答で きるようにするまでには, 時間もかかり, 忍耐も 必要で,またグローバルな共同関係をうまくつくつ ていかねばならない。

QuestionPointは, 米国議会図書館が広範囲な主題, 言語, フォーマットからなる国際的な所蔵資料, および電子レファレンスをサポートする従来の目 録システムを通じて, 質の高いレファレンスサー ビスを提供するという使命を果たす一助となる。 それは, これまで多年にわたる他の図書館との共 同や, 同図書館がこれまで行ってきた情報サービ スの継続にもつながる。しかし, 米国議会図書館 はこれを自館だけでは行わないし, 行えない。世 界中のあらゆる図書館と個別に共同することで, 米国議会図書館とそのパートナー図書館とは, グ ローバルで多様な情報の世界にコントロールと状 況をもたらす。

研究者たちが図書館のリピーター利用者になる ような図書館資源とサービスをつくるために, 新 テクノロジーの刺激と力とをてこにすることこそ， ライブラリアンが今直面する挑戦である。

\section{参考文献}

1) ARNOLDY, B. "Paying for answers online". The Christian Science Monitor. (online), available from<http://www.csmonitor.com/2002/0722/p14s01wmen.html>, (accessed 2002-10-11).

2) COFFMAN, S; McGLAMERY, S. The Librarian and Mr. Jeeves. American Libraries. Vol.20, No.5, 2000, p.66-69.
3) COHEN, L B. Yahoo! and the abdication of judgement. American Libraries. Vol.32, No.1, 2001, p.60-62.

4) QuestionPoint. (online), available from $<\mathrm{http}: / / \mathrm{www}$. questionpoint.org/>, (accessed 2002-10-11).

5) FERGUSON, C D.; BUNGE, C A. The shape of services to come: Values-based reference service for the largely digital library. College \& Research Libraries. 
Vol.58, No.3, 1997, p.252-265.

6) GRAY, S M. Virtual reference services directions and agendas. Reference and User Services Quarterly. Vol.39, No.4, 2000, p.365.

7) HOPPER, I D. New network links up libraries online. Associated Press. Nov. 19, 2000.

8) KATZ, S. In information technology, don't mistake a tool for a goal. The Chronicle of Higher Education Review. Jun. 15, 2001.

9) LEWIS, M. Faking it: the Internet revolution has nothing to do with the NASDAQ. New York Times Magazine. Jul. 15, 2001.

10) LIPOW, A. Strategies for the next millennium: Proceedings of the Ninth Australasian Information Online \& On Disc Conference and Exhibition. Sydney, 1999-01, 1999.

11) McCLURE, C; LANKES, D. "What about the user?". Assessing Quality in Digital Reference Services. Study Bulletin 090101.

12) "Toward a framework for Internet accountability". Markle Foundation. (online), available from $<$ http:// www.markle.org/news/AccountabilityForeword Executive\&Intro.pdf $>$, (accessed 2002-10-11).

13) National Institute of Standards Organization (NISO). (online), available from $<$ http://www.niso.org/>, (accessed 2002-10-11).

14) OCLC Online Computer Library Center, Inc., Office of Research. "Web characterization". OCLC The WEB
Characterization Project. (online), available from $<\mathrm{http}: / /$ wcp.oclc.org/>, (accessed 2002-10-11).

15) PARSONS, A M. "Digital reference: How libraries can compete with Ask-A services". Digital Library Federation Newsletter. Vol.2, No.1, 2001.

16) The Pew Internet \& American Life Project. (online), available from $<$ http://www.pewinternet.org/>, (accessed 2002-10-11).

17) PREER, J. Where are libraries in bowling alone. American Libraries. Vol.32, No.8, 2001, p.60-62.

18) SHERMAN, C; PRICE G. The Invisible Web: Uncovering Information Sources Search Engines Can't Find. 1st ed. Information Today, Inc., 2001, 415p.

19) SLOAN, B. "Ready for reference: Academic libraries offer live Web-based reference". The Graduate School of Library and Information Science University of Illinois at Urbana-Champaign. (online), available from<http://www.lis.uiuc.edu/ $/$ b-sloan/ready4ref.htm>, (accessed 2002-10-11).

20) "Facets of quality for digital reference services. Version 4". The Virtual Reference Desk. (online), available from<http://www.vrd.org/facets-10-00.shtml>, (accessed 2002-10-11).

21) STEPP, L S. "Point. Click. Think?". washingtonpost.com. (online), available from $<$ http:// www. washingtonpost.com/ac2/wpdyn pagename $=$ article $\&$ node $=\&$ content $I d=A 9729$ 2002Jul15\&notFound $=$ true $>$, (accessed 2002-10-11). 